The experience is worth recalling, if only because it shows that evils of this kind are much within the control of the profession itself ; when the profession perceived the evil in its midst the scandal ceased.

April 29tb, 1912. I am, Sir, yours faithfally,

\section{MEDICAL WOMEN FOR INDIA.} To the Editor of THE LANCET.

SIR,-May we appeal through you to Christian medical women for help to be extended to the women of India, whose suffering in the absence of skilled aid in illness can hardly be exaggerated? We have medical work in many parts of India, and every week brings to us letters begging for additions to our staff breaking down through overstrain, and for qualified doctors where there are none. We would emphasise one point. It is those who go out in the spirit of the Lord Jesus Christ who win the hearts of the people. Our hospitals and dispensaries are overflowing with patients who come to them in preference to Government institutions, even where such exist. It is a remarkable fact that during the last fortnight from different quarters a Hindu gentleman and an Indian Christian lady, touched with the sufferings of women in their own neighbourhoods, have alike turned to ns, a Christian society, with offers to provide the salaries of qualified lady doctors, and we have none to send.

A few weeks ago, when, through stress elsewhere, the closing of one of our hospitals in the Punjab was imminent, a petition signed by the leading men of the town was sent to us, beseeching that such a calamity to their families as the removal of the beloved doctor might be averted. For the moment, through unexpected temporary help, the situation has been saved. But unless recruits can be found, like sad catastrophes must soon occur, and, of course, appeals to occupy new districts must remain unanswered. Are there none in this land ready to come forward for this noble work in the name of our faith and for our Empire? May I add that China presses on ns with hardly less powerful claims, and that money gifts are also of great value for the work of our society? I am, Sir, yours faithfully,

ANNA M. L. SMITH,

Church of England Zenana Missionary Society, Honorary Foreign Secretary

27, Chancery.lane, W.C. April 20th, 1912 .

\section{THE EFFECTS OF MENSTRUATION AND OF THE CLIMACTERIC.}

\section{To the Editor of THE LANCET.}

SIR,-1. Will some of your readers give me information as to how far they have observed in their own experience as physicians that their patients are affected or are " subnormal" during menstrual period or climacteric: (a) physically, (b) mentally, (o) zsthetically, (d) morally, (e) spiritually (religious excitement)?

2. What percentage of their patients are affected or subnormal in each of these five directions?

3. Are the patients upper, middle, or lower class?

I shall be glad to reciprocate by forwarding the consensus of opinion to anyone replying, if a sufficient number of replies be received. Communications should be addressed care of Dr. J. Bullowa, 62, West 87th Street, New York, U.S. America. - I am, Sir, yours faithfully, April 25th, 1912. H. P. MENDES, M.D.

\section{SCHOOLS FOR TUBERCULOUS CHILDREN.} To the Editor of THE I.ANCET.

SIR,- Your report in THE LANCET regarding the International Congress on Tuberculosis credits me with a communication to which I have no claim. Apart from the general address delivered to the whole congress and occasional remarks when I happened to preside at the sections, I made no formal communication. I should not trouble you with this save for the reason that $I$ fear in the considerable confusion which existed your correspondent may have been led to suppose that a paper delivered (not read) in Italian by Miss Ethel McGaw on the subject of schools for taberculous children was mine. For the purpose of illustrating the open-air school copies of a descriptive statement prepared by me at the request of the Italian committee, with photographs of the various elements in our anti-tuberculosis scheme, were passed round. This probably led to the mistake. Miss McGaw's paper was a delightfully clear and simple statement of her views regarding the need for tuberculosis schools, and included a too modest account of what has been achieved at the Kensal House School and in Marylebone. The paper made a marked impression on the Italians present. Miss McGaw was nominated a vicepresident of the section. I am, Sir, yours faithfully,

Edinburgh, April 27th, 1912. R. W. PHILIP.

\section{RADIUM EMANATIONS IN MINERAL WATERS.}

To the Editor of THE LANCET.

SIR,-In your report in THE LANCET of April 20th of Mr. T. Pagan Lowe's excellent paper read at the Royal Society of Medicine on the above subject, I am pleased to find that he confirms, from his own personal observations, eleven important results of radium water therapy. He credits these, however, to Dr. Aikins and Dr. Harrison, who published them in the Canadian Practitioner in August, 1911. I shonld like to point out that the "results" quoted clargely the outcome of my own investigations) were published in my paper on " Radium Water Therapy " in the British Medical Journal of A pril 27th, 1911. I am, Sir, yours faithfully,

Buxton, April 29th, 1912.

WM. Armstrong.

\section{BOILED MILK.}

To the Editor of THE LANCET.

SIR,-In view of the Local Government report and your leader on the value of boiled milk as a food for infants, ${ }^{1}$ it may not be out of place to remind all concerned that when milk has once been boiled it needs to be carefully protected from contamination, especially by flies or dust, because when once the lactic acid bacteria have been destroyed by boiling, putrefactive and other bacteria gaining access to milk have unrestrained opportunities of multiplication, and such milk is apt to putrefy and acquire dangerous properties without showing signs of "souring." The absolute cleanliness of every vessel used for "boiled milk" is a sine qua non if danger is to be averted.

I am, Sir, yours faithfully,

Norwich, April 29th, 1912. J. T. O. NASH.

\section{THE MEDICAL PROFESSION AND THE NATIONAL INSURANCE ACT. To the Editor of THE LANCWT.}

SrR,-On March 23rd you were good enough to publish a letter by me in which $\hat{I}$ urged all my confrères engaged in general practice to test the working of a plan by which eacs may discover for himself the equivalence of the $2 s .6 d$. per visit to premium-to find out what premium would be required to cover payment for work done. The plan described also gives, of course, the average payment per head of all those who are charged $2 s .6 d$. per visit. I pointed out that it is absolutely essential to know how much per head per annum the population below income-tax limit pays us in fees so that we can compare that amount (when averaged) with the Government offer of $6 s$. and our claim of $8 s$. $6 d$.

Of course, I can only draw conclusions from my own practice, but they are of guch an astounding nature that I cannot in discretion ask you to publish the figures. (They are, however, inclosed for your inspection.) I will merely say that the sum offered us is astonishingly generous in its relation to the figures disclosed by $\mathrm{my}$ investigation. If we are prepared to be content with a preminm that would give us returns not less than would be given by payment for work done at $2 s .6 d$. per visit, then I say with all emphasis that in the terms of the Act we are offered all that we claim.

Is not our claim of $8 s .6 d$. supposed to represent an equivalence with payment for work done at $2 s .6 d$. per visit? In 